\title{
Impact of industrial specialization and economic development on income inequality in the regions of Russia
}

\author{
Natalia Davidson $^{1^{*}}$, Stepan Bakhteyev ${ }^{1}$, and Sophia Turkanova ${ }^{1}$ \\ ${ }^{1}$ Ural Federal University, Graduate School of Economics and Management, Mira str.19, Ekaterinburg, \\ 620002, Russia
}

\begin{abstract}
The degree of income differentiation depends on many factors, including the level of regional economic development, production structure and industrial specialization. In this paper, we assess the impact of the industrial specialization of Russian regions on income inequality measured by the Gini coefficient. Based on the regional data over the period 2005 to 2018, we build an econometric model applying the Arellano-Bover / Blundell-Bond estimation method. We use shares of the main industries in gross regional product to describe production structure of regions. The modelling results show that the classic Kuznets curve is not empirically supported for the regions of Russia. Besides, we find that the larger the share of mining, manufacturing, construction, trade and financial sector in GRP, the higher the inequality in the region, while the share of agriculture does not affect it significantly.
\end{abstract}

Keywords: regional inequality, industrial specialization, incomes of the population.

\section{Introduction}

In recent decades, the combination of rapid economic development at the national and regional levels and growing social inequality has attracted a growing public attention. Among the Sustainable Development Goals defined by the United Nations (UN) in 2015 are measures aimed at reducing poverty and inequality and creating strong institutions.

The world economy has achieved an impressive success in economic development. However, high income differentiation among population remains a significant problem, leading to adverse social consequences. These consequences include a decrease in social mobility and in capital inflows, an increase in crime, and to social and political instability [1].

Russia shows a high level of inequality in comparison with the European countries. At the same time, relative to the BRICS countries and the United States, Russia has a relatively lower income differentiation [2].

\footnotetext{
${ }^{*}$ Corresponding author: natalya.davidson@gmail.com
} 
This paper assesses the impact of industrial specialization of Russian regions on income inequality. Besides, we test the hypothesis of the Kuznets curve on the influence of the regional economic development on inequality.

\section{Literature review}

A seminal theoretical work devoted to the relationship between economic development and income inequality is the study by Simon Kuznets. He proposed an inverted U-shaped relationship between average per capita income and the level of income inequality [3]. The Kuznets curve suggests that as an economy develops, income inequality first increases, and then gradually decreases.

However, recent studies show that for some countries the hypothesis of the Kuznets curve is not observed $[4,5]$. In the existing literature, there are empirical assumptions not about an inverted U-shaped relationship between inequality and the level of economic development, but about an N-shaped one. This implies that the most developed regions face a consistent increase in the inequality level after reaching a certain level of economic development [6].

The empirical instability of the Kuznets curve is accompanied by the statement that inequality depends not only on the pace and stage of regional economic growth, but also on institutions and the type of economic development [3]. In particular, the type of economic development is associated with product specialization.

Income inequality depends on many factors, such as geographical location of the region, the accessibility of production factors, institutional quality, and social capital $[3,7]$. Using the information about the product specialization of the region, it is possible to draw certain conclusions about the characteristics of these factors for the regions. For example, regions specializing on the agricultural products have a more uneven distribution of power and wealth $[3,8]$. Regions with a more complex production structure associated with high-tech systems are usually more diversified, have better developed institutions and human capital, and, therefore, a lower level of inequality.

The set of products of the regional economy defines the choice of a profession, opportunities for local training, and the activities of trade unions. The industrialization of some developing countries has led to the emergence of new jobs, better educational opportunities, and an increase in the share of the middle class. At the same time, the deindustrialization of developed countries and their struggle for leadership in the export of industrial goods has resulted in an increase in the differentiation of population income [9].

The transition from agriculture to industry increases the regional technological potential. Technological development increases productivity and efficiency, but also increases demand for skilled labour and the premium for the qualified employees. It also reduces demand for low-skilled workers due to automation, which leads to an increase in income inequality [10].

The production structure of the region can influence inequality through the development of human capital. Human capital can be measured as the percentage of the population with a higher education. Indicators of the social capital and institutional development can significantly affect inequality by increasing the incentives of the population to join trade unions, determining the minimum wage, and creating contributions to social insurance funds. This reduces inequality through convergence of income across different population groups [11].

The development of advanced industries can lead to the dispersion of skills and knowledge among the population and the expansion of class consciousness [12]. This can lead to a reduction in inequality by expanding professional opportunities for people with all levels of professional qualification, and increasing the employees' bargaining power regarding remuneration. At the same time, the regional specialization on the products of 
lower complexity and the products not requiring special training creates a situation when the economic benefits go to a limited number of people with high incomes.

\section{Data and methodology}

\subsection{Data description}

Our research is based on panel data for 77 regions of Russia for the period over 2005 to 2018 . The data sources are the Federal State Statistics Service (Rosstat), the Unified Interdepartmental Statistical Information System (UISIS) and the Federal Service for State Registration, Cadastre and Cartography (Rosreestr). The data description is presented in Table 1.

In this paper, we use the Gini index as an indicator of inequality in the population incomes. In many works devoted to income inequality, this indicator is also used as the dependent variable $[8,9,12]$.

The explanatory variables are GRP per capita and its square, shares in the GRP of 6 sectors of the economy, which can affect inequality, foreign direct investment (FDI) [13], population density [14] and unemployment rate $[8,15]$.

The population density in the region was obtained based on the Rosstat data on the (estimated) population size in the regions of the Russian Federation and Rosreestr data on the area of the Russian regions.

Table 1. Description of the data.

\begin{tabular}{|c|c|c|c|}
\hline Variable & $\begin{array}{c}\text { Unit of } \\
\text { measurement }\end{array}$ & Data source & $\begin{array}{c}\text { Expected } \\
\text { relationship }\end{array}$ \\
\hline \multicolumn{4}{|c|}{ Dependent variable } \\
\hline Gini index & $\%$ & UISIS & \\
\hline \multicolumn{4}{|c|}{ Explanatory variables } \\
\hline GRP per capita & $\begin{array}{l}\text { Russian } \\
\text { rubles }\end{array}$ & Rosstat & $\begin{array}{l}\text { Inverted U- } \\
\text { shaped } \\
\text { relationship }\end{array}$ \\
\hline Share of agriculture in GRP & $\%$ & Rosstat & + \\
\hline Share of construction in GRP & $\%$ & Rosstat & + \\
\hline Share of trade in GRP & $\%$ & Rosstat & + \\
\hline Share of finances in GRP & $\%$ & Rosstat & + \\
\hline Share of manufacturing in GRP & $\%$ & Rosstat & + \\
\hline Share of mining in GRP & $\%$ & Rosstat & + \\
\hline $\begin{array}{l}\text { Foreign direct investment in the } \\
\text { region }\end{array}$ & USD million & Rosstat & - \\
\hline $\begin{array}{l}\text { Share of workforce with higher } \\
\text { education }\end{array}$ & $\%$ & Rosstat & - \\
\hline $\begin{array}{l}\text { Share of workforce with secondary } \\
\text { vocational education }\end{array}$ & $\%$ & Rosstat & - \\
\hline Population density & people / km2 & $\begin{array}{c}\text { Calculations based } \\
\text { on data from } \\
\text { Rosstat and } \\
\text { Rosreestr }\end{array}$ & + \\
\hline $\begin{array}{l}\text { Unemployment rate (according to } \\
\text { ILO methodology) }\end{array}$ & $\%$ & UISIS & + \\
\hline
\end{tabular}

Table 2 provides descriptive statistics for the variables. The average value of the Gini index in the Russian regions in the study period is $38.24 \%$. On average, the largest share in 
GRP among the represented industries belongs to manufacturing, while the smallest share belongs to the financial sector. There is a high differentiation of regions: in some regions, the share of the industry is zero, and in others it accounts for more than half of the entire economy. The regions also differ substantially in terms of per capita GRP, population density, unemployment rate and the volume of attracted FDI. Based on these conclusions, the decision to use standard errors that are robust to heteroscedasticity is justified.

Table 2. Descriptive statistics.

\begin{tabular}{|l|c|c|c|c|c|}
\hline \multicolumn{1}{|c|}{ Variable } & $\begin{array}{c}\text { No. of } \\
\text { observations }\end{array}$ & Mean & $\begin{array}{c}\text { Standard } \\
\text { deviation }\end{array}$ & Min & Max \\
\hline Gini index & 1.078 & 38.24 & 2.38 & 31.60 & 46.50 \\
\hline GRP per capita & 1.078 & 85299.02 & 66801.87 & 10319.57 & 592902.90 \\
\hline Share of agriculture in GRP & 1.078 & 9.36 & 5.73 & 0.60 & 36.60 \\
\hline $\begin{array}{l}\text { Share of construction in } \\
\text { GRP }\end{array}$ & 1.078 & 8.49 & 13.29 & 0.00 & 71.00 \\
\hline Share of trade in GRP & 1.078 & 18.37 & 10.57 & 0.20 & 58.50 \\
\hline Share of finances in GRP & 1.078 & 7.61 & 3.41 & 1.80 & 31.80 \\
\hline $\begin{array}{l}\text { Share of manufacturing in } \\
\text { GRP }\end{array}$ & 1.078 & 13.74 & 4.48 & 3.70 & 28.50 \\
\hline Share of mining in GRP & 1.078 & 0.25 & 0.31 & 0.00 & 6.10 \\
\hline $\begin{array}{l}\text { Foreign direct investment } \\
\text { in the region }\end{array}$ & 1.078 & 375.57 & 1196.63 & 0.00 & 14100.00 \\
\hline Population density & 1.078 & 52.11 & 129.14 & 0.06 & 1038.19 \\
\hline Unemployment rate & 1.078 & 7.60 & 5.27 & 2.00 & 63.10 \\
\hline $\begin{array}{l}\text { Share of workforce with } \\
\text { higher education }\end{array}$ & 1,078 & 27.60 & 4.90 & 15.60 & 48.60 \\
\hline $\begin{array}{l}\text { Share of workforce with } \\
\text { secondary vocational } \\
\text { education }\end{array}$ & 1,078 & 45.67 & 6.51 & 19.00 & 61.20 \\
\hline
\end{tabular}

\subsection{Empirical strategy}

We estimate the following econometric model:

$$
\begin{aligned}
& \text { gini }_{i, t}=a_{i, t}+\beta_{1} \ln G R P_{i, t}+\beta_{2}(\ln G R P)^{2}{ }_{i, t}+\beta_{3} \text { agri }_{i, t}+\beta_{4} \text { construc }_{i, t}+ \\
& \beta_{\text {strade }}+, t+\beta_{6} \text { finance }_{i, t}+\beta_{7 \text { manuf }}+\beta_{i, t}+\beta_{8 \text { mining }_{i, t}}+\delta \mathbf{X}_{i, t}+\eta_{i}+\varepsilon_{i, t}
\end{aligned}
$$

where gini $_{i, t}$ is the Gini coefficient in region $\mathrm{i}$ at time $\mathrm{t}, G R P_{i, t}$ is GRP of region $\mathrm{i}$ at time $\mathrm{t}$, agri $_{i, t}$, construc $_{i, t}$, trade $_{i, t}$, finance $_{i, t}$, manuf $_{i, t}$, mining $_{i, t}$, are shares of agriculture, construction, trade, financial sector, production and mining in region $i$ at time $t, \mathbf{X}_{i, t}$ is a vector of control variables, $\eta_{\mathrm{i}}$ is an unobservable regional effect, and $\varepsilon_{i, t}$ is error term.

We estimate this equation using the Arellano-Bover/Blundell-Bond method [16, 17]. This technique is applied to deal with endogeneity that is likely to be present in the model. The reason for that can be omission of significant variables that change over time, including the regional policy and population migration. The dynamism of such factors does not allow models with fixed effects to completely neutralize the influence of unobserved effects, therefore, the estimates would be biased.

The Arellano-Bover/Blundell-Bond estimation method allows using lags of dependent variables as tools. This is possible due to the assumption that the past values of variables do not affect future errors, but correlate with regressors. Besides, in this approach the generalized method of moments is applied. 
In order to check the consistency of the model, the Arellano-Bond test was used. To get valid results, we took 3 lags of the dependent variable. The next section presents and discusses the results.

\section{Results and discussion}

The estimation results are presented in Table 3.

Table 3. Estimation results.

\begin{tabular}{|c|c|c|c|c|}
\hline \multirow[b]{2}{*}{ Explanatory variables } & \multicolumn{4}{|c|}{ Dependent variable: Gini index } \\
\hline & $\begin{array}{c}\text { Kuznets } \\
\text { curve }\end{array}$ & $\begin{array}{c}\text { Industrial } \\
\text { specialization }\end{array}$ & $\begin{array}{l}\text { FDI, density, } \\
\text { unemployment }\end{array}$ & $\begin{array}{c}\text { Education } \\
\text { factor }\end{array}$ \\
\hline Gini index (t-1) & $\begin{array}{l}0.953 * * * \\
(0.0286)\end{array}$ & $\begin{array}{l}0.889 * * * \\
(0.0400) \\
\end{array}$ & $\begin{array}{l}0.854 * * * \\
(0.0404) \\
\end{array}$ & $\begin{array}{l}0.731 * * * \\
(0.0412) \\
\end{array}$ \\
\hline Gini index $(t-2)$ & $\begin{array}{l}0.163^{* * *} \\
(0.0454)\end{array}$ & $\begin{array}{l}0.153 * * * \\
(0.0433) \\
\end{array}$ & $\begin{array}{l}0.153 * * * \\
(0.0439) \\
\end{array}$ & $\begin{array}{l}0.0833^{*} \\
(0.0437)\end{array}$ \\
\hline Gini index $(t-3)$ & $\begin{array}{c}-0.243 * * * \\
(0.0322)\end{array}$ & $\begin{array}{c}-0.213 * * * \\
(0.0318)\end{array}$ & $\begin{array}{c}-0.202 * * * \\
(0.0327) \\
\end{array}$ & $\begin{array}{c}-0.138^{* * *} \\
(0.0346) \\
\end{array}$ \\
\hline GRP per capita, logarithm & $\begin{array}{c}-16.24 * * * \\
(4.717) \\
\end{array}$ & $\begin{array}{c}-15.96 * * * \\
(5.902)\end{array}$ & $\begin{array}{c}-13.76^{* *} \\
(5.379) \\
\end{array}$ & $\begin{array}{c}-15.60 * * * \\
(5.719) \\
\end{array}$ \\
\hline $\begin{array}{l}\text { GRP per capita, logarithm } \\
\text { squared }\end{array}$ & $\begin{array}{c}0.718^{* * *} \\
(0.208) \\
\end{array}$ & $\begin{array}{l}0.674^{* *} \\
(0.262) \\
\end{array}$ & $\begin{array}{l}0.595^{* *} \\
(0.239) \\
\end{array}$ & $\begin{array}{c}0.720^{* * * *} \\
(0.254) \\
\end{array}$ \\
\hline Share of agriculture in GRP & & $\begin{array}{l}-0.0171 \\
(0.0233)\end{array}$ & $\begin{array}{l}-0.0146 \\
(0.0243)\end{array}$ & $\begin{array}{l}-0.0155 \\
(0.0220)\end{array}$ \\
\hline Share of mining in GRP & & $\begin{array}{c}0.0684 * * * \\
(0.0171)\end{array}$ & $\begin{array}{c}0.0616^{* * *} \\
(0.0182)\end{array}$ & $\begin{array}{c}0.0213 \\
(0.0167)\end{array}$ \\
\hline $\begin{array}{l}\text { Share of manufacturing in } \\
\text { GRP }\end{array}$ & & $\begin{array}{c}0.0872 * * * \\
(0.0173)\end{array}$ & $\begin{array}{c}0.0896^{* * *} \\
(0.0196)\end{array}$ & $\begin{array}{l}0.0362 * * \\
(0.0179)\end{array}$ \\
\hline $\begin{array}{l}\text { Share of construction in } \\
\text { GRP }\end{array}$ & & $\begin{array}{c}0.0637 * * * \\
(0.0195)\end{array}$ & $\begin{array}{c}0.0607 * * * \\
(0.0202)\end{array}$ & $\begin{array}{l}0.0437 * * \\
(0.0185)\end{array}$ \\
\hline Share of trade in GRP & & $\begin{array}{l}0.111 * * * \\
(0.0262)\end{array}$ & $\begin{array}{l}0.121 * * * \\
(0.0258)\end{array}$ & $\begin{array}{c}0.0735^{* * *} \\
(0.0235) \\
\end{array}$ \\
\hline Share of finances in GRP & & $\begin{array}{c}0.658^{* * *} \\
(0.157)\end{array}$ & $\begin{array}{c}0.683 * * * \\
(0.163)\end{array}$ & $\begin{array}{c}0.544 * * * \\
(0.153)\end{array}$ \\
\hline $\begin{array}{l}\text { Foreign direct investment, } \\
\text { logarithm }\end{array}$ & & & $\begin{array}{c}-0.0589^{* *} \\
(0.0229)\end{array}$ & \\
\hline Population density & & & $\begin{array}{c}0.00483 \\
(0.00560) \\
\end{array}$ & \\
\hline Unemployment rate & & & $\begin{array}{c}0.0243 \\
(0.0319)\end{array}$ & \\
\hline $\begin{array}{l}\text { Share of workforce with } \\
\text { higher education }\end{array}$ & & & & $\begin{array}{c}-0.120 * * * \\
(0.0179)\end{array}$ \\
\hline $\begin{array}{l}\text { Share of workforce with } \\
\text { secondary vocational } \\
\text { education }\end{array}$ & & & & $\begin{array}{l}-0.00804 \\
(0.0122)\end{array}$ \\
\hline Constant & $\begin{array}{c}96.31 * * * \\
(26.48)\end{array}$ & $\begin{array}{c}96.35 * * * \\
(32.72)\end{array}$ & $\begin{array}{c}82.31 * * * \\
(30.05)\end{array}$ & $\begin{array}{l}98.19 * * * \\
(31.68)\end{array}$ \\
\hline No. of observations & 847 & 847 & 847 & 847 \\
\hline
\end{tabular}

*** significant at the $1 \%$ level, ${ }^{* *}$ - at the $5 \%$ level, ${ }^{*}$ - at the $10 \%$ level. The standard errors are in parentheses.

Based on the results of evaluating all 4 models, we see that the Kuznets curve hypothesis is not confirmed for the Russian regions. Instead of the expected dependence in the inverted $\mathrm{U}$-shaped form, we received a dependence in the form of an ordinary letter "U". The failure 
of empirical confirmation of the hypothesis can probably be explained using the hypothesis of an N-shaped dependence [6]. In other words, the Russian regions have already passed the peak of the Kuznets curve, and we are seeing a repeated increase in inequality. This result is consistent with many empirical studies conducted earlier $[4,5,8]$.

Our expectations about the impact of the regional industrial specification were justified. According to the estimation results, only the share of the agricultural sector in GRP does not have a significant impact on the Gini index. At the same time, we obtained results indicating the insignificance of the share of mining in GRP in the model with education, while the significance of estimates for the construction sector and the manufacturing sector has decreased in this model. The reason is probably that these industries require a lot of educated workers, so the inclusion of this factor in the model "pulls" the explanatory power of these variables. The rest of the industries, as we expected, have a significant and positive impact on inequality in the regions. We note a significant and positive effect of the financial sector share on the Gini index. According to our data (table 2), the financial sector accounts for a relatively low share of GRP (up to zero) in the regions, therefore, it is reasonable to assume that in the regions where it is presented, inequality increases dramatically.

It is worth noting that according to our results an increase in foreign direct investment and the share of employees with higher education reduce inequality in the regions. These results are consistent with previous studies $[10,13]$. This outcome should be considered while developing regional policy.

\section{Conclusion}

In this study, we evaluated 4 models to find the impact of the sectoral structure of the economy on income inequality. The obtained results allowed us to draw several conclusions.

First, the classical Kuznets curve is not confirmed empirically on Russian data, supporting the assumption of the N-shaped relationship.

Second, the results of our work confirm the hypothesis about the influence of the regional sectoral structure on income inequality, namely, that the greater the share of manufacturing, construction, trade and financial sector in GRP, the higher the inequality in the region. At the same time, we find no evidence that the share of agriculture in GRP affects inequality. Besides, we show that the share of mining is insignificant when education is included in the model.

Based on these conclusions, we suggest that regions with a low share of agriculture and the dominance of other industries in GRP take into consideration that such economic structure increases income inequality. This conclusion is in line with economic intuition, and a rational solution would be to stimulate FDI, which, according to our results, reduces the level of inequality. It is also important for the regions to improve the quality of higher education and to attract workers with higher education from the other regions. This is crucial since workers with higher education have more opportunities in the labor market and can claim higher salaries; besides, they can create more favorable conditions for the others, this way decreasing inequality.

Acknowledgement: Research was supported by the grant of the Russian Science Foundation № 1918-00262 "Empirical modelling of balanced technological and socioeconomic development in the Russian regions".

\section{References}

1. D. Acemoglu, J. A. Robinson, Why nations fail: The origins of power, prosperity, and poverty (2012) 
2. S. Mareeva, Monetary inequality in Russia in the sociological dimension. URL: https://econs.online/articles/opinions/monetarnoe-neravenstvo-v-rossii/. (2021)

3. S. Kuznets, Am Econ Rev, 45, 1-28 (1955)

4. J. G. Palma, Dev and Chan, 42(1), 87-153 (2011)

5. S. Makreshanska-Mladenovska, G. Petrevski, Post-Comm Econ, 31(1), 123-136 (2018)

6. A. S. Alderson, et al. How has income inequality grown? The reshaping of the income distribution in LIS countries. Inequality and The Status of The Middle Class: Lessons from the Luxembourg Income Study. Luxembourg (2010)

7. T. Piketty, Capital in the twenty-first century. HUP (2018)

8. D. Castells-Quintana, R. Ramos, V. Royuela, Review of Regional Research, 35(2), 123-146 (2015)

9. B. Milanovic, Global income inequality by the numbers: in history and now-an overview (2012)

10. C. Calderón, A. Chong, Pub Choi, 138(1), 65-81 (2009)

11. D. Hartmann, et al. W dev, 93, 75-93 (2017)

12. M. Brzezinski, Econ Sys, 42(2), 219-247 (2018)

13. K. Josifidis, N. Supic, O. Glavaski, East Eu Econ, 56(6), 1-19 (2018)

14. A. Suárez Álvarez, A. J. López Menéndez, Bull Econ Res, 1, 25 (2021)

15. B. Anghel, H. Basso, O. Bover, J. M. Casado, L. Hospido, M. Izquierdo, I. A. Kataryniuk, A. Lacuesta, J. M. Montero, E. Vozmediano, SERIEs J Span Econ Assoc, 9, 351-378 (2018)

16. M. Arellano, O. Bover, J Economet, 68, 29-51 (1995)

17. R. Blundell, S. Bond, J Economet, 87, 115-143 (1998) 